\title{
PROTECTING DEPORTABLE ALIENS FROM PHYSICAL PERSECUTION: SECTION 243(h) OF THE IMMIGRATION AND NATIONALITY ACT OF 1952
}

Aliens deported from the United States may face treatment repugnant *" American standards of justice upon arrival at their final destination. Merely because of political or religious beliefs which are disfavored by the reseiving government, for example, they may be subjected to death, torture, or inprisonment. Some of these aliens are deported because they have engaged in sul; = versive or criminal activities. ${ }^{1}$ The large majority, however, are relatively harmless individuals whose only offense has been failure to comply, perhays inadvertently, with technical immigration regulations." In riew of the rigidity with which the immigration acts are oiten applied, explicit statutory protection for both classes of aliens from such drastic consequences is essential.

Congress first attempted to deal with this problem in the Internal Security Act of $1950 .^{3}$ Section 23 of that Act ofiered to individuals who had lieen

1. Deportation for such activities is now grovided for by the Immigration and Jiatisiality Act of 1952 ("The McCarran Act"), Pub. L. No. 414, 82d Cong., 24 Sus5. \$3 241 (41, (6)-(7), (11)-(18) (June 27, 1952). Of the 40.212 aliens deported from the United States in the period 1949-51, 3.261 vere deported because of criminal or subverive

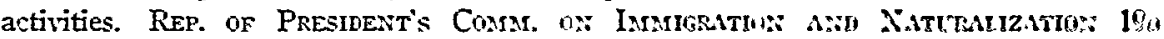
(1952). It seems likely that this number will increase in the future tasuse of tits broader provisions for deportation on political grounds contained in the McCarran Act. For a brief history of the increasing use of undesirable political activity as a basis for

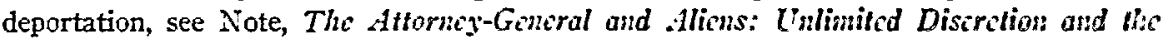
Right to Fair Treatmcnt, 60 Y.ALE L.J. 152 (1951). For estensive discussiun of current problems pertaining to immigration and naturalization, sce Dcciopancuts in the La:Immigration and Naturaliation, $66 \mathrm{HARv}$. L. Rev. 643 (1953).

2. Of the 40,212 aliens deported from the Lnited States in the period $144 y-51,29,1 \geq 3$ were charged with violation of immigration regulations portaining to cntry and stisu. In 1951, 3,289 of 13,544 aliens deported were charged with remaining in the country longer than authorized. An additional 5,322 were deforted because they had entercd vithout proper documents, without inspection, or by false statemints. KEP. WF [PESES: Conni. ox Ianigration and Naturalization 196 (1952). Of this sccond groug's plight it has been said: "Mlany of the immigration requirements are highly technieal. . . . In many . . . cases the alien himself has nothing to do vith the actual compliance with the technicalities of the law. A failure to observe these or a multitude of other technical requirements makes the alien's entry irregular and therefore under fresent law rendsrs him subject to expulsion." Id. at 196-7.

It is estimated that there are three to five million aliens illegally in the Cnited States. 98 Cosig. REC 5172 (1952). For the current legislative provisions setting up the tcchnicalities which may trip up the unwary alien, see Pub. L. No. 414, \&2d Cong., $2 d$ Sess. \&s 241 (2), (5), (9) (June 27, 1952).

3. 64 STat. 987 (1950), 8 U.S.C. $\$ 156$ (Supp. 1951 ).

4. Section 23 amended $\S 20$ of the Immigration Act of 1917. 39 Sr.1r. $\$ 74$ (1917), 28 U.S.C. $\$ 156$ (1946). Both sections dealt generally with the methods to le emplovid in determining the country to which an undesirable alien was to be deportcd.

For a statement of the motives which prompted the passage of tire Iysu ligriattur, see Park v. Barber, 107 F. Supp. 605, 600 (N.U. Cal. 1952), and sources thirein ats.d. 
classified as deportable aliens the right to have deportation suspended if they faced physical persecution in the country designated to receive them. The section provided that:

"No alien shall be deported under any provisions of this chapter to any country in which the Attorney General shall find that stuch alien would be subjected to physical persecution."

In the recently enacted Immigration and Nationality Act of $1952^{\circ}$ the provisions of Section 23 have been been significantly altered. Section 243(1) of the new Act states:

"The Attorney General is authorized to withhold deportation of any alien within the United States to any country in which in his opinion the alien would be subject to physical persecution and for such period of time as he deems to be necessary for such reason."

The new law differs from the old in two important respects. First, under the new wording only an opinion, rather than a finding of fact, is required

5. The procedures employed in the 1950 Act to determine the country to which a deportable alien was to be sent are outlined in 64 STAT. 987 (1950), \& U.S.C. $\$ 156$ (Supp. 1951).

Under current law the Attorney General must deport an alien to the country of his choice if that country is willing to accept him. Pub. L. No. 414, $82 \mathrm{~d}$ Cong., $2 \mathrm{~d}$ Sess. $\$ 243$ (a) (June 27, 1952). The alien is allowed to make only one such designation, however, and the Attorney General may refuse to deport to the designated country if "in his discretion, [he] concludes that deportation to such country would be prejudicial to the interests of the United States." Ibid. In the event that the alien fails to make a designation (see.United States ex rel. Nereo Dolenz v. Shaughnessy, 107 F. Supp. 611 (1952)), or the country which he designates refuses to accept him (see United States exr rel. Watts v. Shaughnessy, 107 F. Supp. 613 (1952)), the Attorney General may deport to practically any country that he desires. Ibid.

6. Pub. L. No. 414, 82d Cong., 2d Sess. (June 27, 1952).

7. As originally phrased in S. 2550 and H.R. 5678 the provision read: "No alien shall be deported under any provisions of this act to any country in which the Attorney General in his discretion finds that such alien would be subject to physical persccution." The congressional committees reporting out these bills stated: "The bill continues the provision in existing law to the effect that no alien shall be deported to any country in which the Attorney General finds that he would be subjected to physical persecution." H.R. REP. No. 1365, 82d Cong., 2d Sess.; SEN. Rep. No. 1137, 82d Cong., 2d Sess. (1952).

"The change in the language of the provision as it now appears in the Immigration and Nationality Act ... was motivated by a desire to clarify the provision to make it perfectly clear that a determination of whether or not the deportation of an alien should be withheld in such cases is solely within the discretion of the Attorney General." Communication to Yale LAw Joursal from Senator Pat MfCarran (D. Nev.), dated Jan. 17, 1953, in Yale Law Library.

For criticism of the McCarran Act's numerous grants of discretionary authority to the Attorney General, see Rep. of President's Comis. on Imsugration and Naturalization Xv, 16-19 (1952); see also President Truman's message to Congrcss accompanying his veto of the McCarran Act, N.Y. Times, June 26, 1952, p. 4, col. 7; and Communication to Yale LAw Jorknal from Senator Hubert H. Humphrey (D. Minn), dated Jan. 23, 1952, in Yale Law Library. 
of the Attorney General ${ }^{s}$ on the question of physical persecution. Second. even when it is evident that an alien if deported woulh face phy ical persecution. suspension appears entirely discretionary. The Attorney General is "authorized" but not required to withhold deportation."

The language of the 1950 . Act merely prohibited depurtation where the Attorney General found that an alien could be persecuted; but the courts required the Attorney General to make a finding that the alien cootd not be persecuted. ${ }^{10}$ To reach such a finding, a hearing in accordance with the requirements of procedural due process had to he conducted. ${ }^{11}$ In tirree cases where aliens introduced evidence of probable physical persecution, district court: refused to allow the Attorney General simply to dismiss the claims on the ground that they were unconvincing or unsupported. ${ }^{12}$ On the facts bisfore them, at least. the courts seemed to require the Immigration authorities to introduce some affirmative evidence that the aliens would not lie persecuted before they would permit deportation. And in one of the cases, the court refused to accept a finding against the alien in which the sole evidence adverse to his claim was a written assertion-made by the receiving country's ambassador-that the alien would not be subject to persecution. ${ }^{13}$ On the ather hand, only in United States ex rel. Dolma a. Shaughnessy it did a district

8. The original procedures relating to the apprehension and rcmonal of deportabls: aliens are conducted by the Immigration and Naturalization Service of the Department of Justice. Appeals from decisions of the Scrvice are dceided by the Eeard of Immigration Appeals. The Board functions independently of the Service and serves to come entent as an agent of the Attorney General in deportation matters. The Attorney Goneral es= ercises final authority, however. Pub. L. No. 414, \$2d Cong., 2d Sess. $\$ 103(2)$ (June 27, 1952). He has been granted broad authority to delcgate his powers under the statute. Ihid. For a history of the development of the adminstration of the immigration laws,

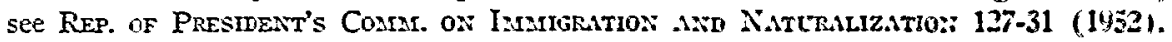
(1952).

9. Under the 1950 Act, "[C]ongress gave a mandatory inflectiun to its words. It said that 'No alien shall be deported' ...." Fark v. Barber, 107 F. Supp. 605, 607 (N.D. Cal. 1952). And 62 STAT. 1206 (1948), S U.S.C. $\$ 155$ (c) (Supp. 1051) gave the Atturncy General discretionary power to grant suspension of deportation in eases of cconcmic hardship. In construing the power granted under $\$ 155(c)$, the Sccond Circuit said: "[T] he statute does not say that the Attorney Gueral must suspend dspurtation; it only says that he "may'" United States cx rel. Weddelie v. Wathins, 166 F.21 369, 373 (24 Cir.), cert. denied, 333 U.S. $\$ 76$ (194\$).

10. Section 23 was first construed in this manner in Unitcd Stats ex rel. Harisiades v. Shaughnessy, 187 F.2d 137 (2d Cir.), aff d, 342 U.S. 580 (1951).

11. "In the face of this requirement of a finding, these relators cannot le deprivel of a hearing and a reasoned determination." United States ca rol. Chen Ping Zee v. Shaughnessy, 107 F. Supp. 607, 610 (S.D.N.Y. 1952). See also tnitcd States co rcl. Watts v. Shaughnessy, 107 F. Supp. 613 (S.D.N.Y. 1952) ; Park v. Earber, 107 F. Sugp. 603 (N.D. Cal. 1952) (injunction against deportation), furhicr proccedings, id. at 605 (release ordered).

12. See United States $e x$ rel. Chen Ping Zee v. Shaughnessy, sufra note 11; Cnitul States ex rel. Watts v. Shaughnessy, sispra note 11; Park v. Barber, sispra nute 11.

13. Fark v. Barber, 107 F. Supp. 605 (N.D. Cal. 1952).

14. 107 F. Supp. 611 (S.D.N.Y. 1952). 
court explicitly read the statute as not requiring the Attorney General to present any adverse evidence; it allowed him to make his finding purely from a reasonable evaluation of the evidence presented by the alien.

The judicial protection thus afforded by a majority of courts under the 1950 Act may be eliminated by the new law. Since only an "opinion" rather than a "finding" is specified, the courts may no longer require a formal hearing on the alien's claim of physical persecution. ${ }^{10}$ And even if they shoukl conclude that a hearing is essential, it seems likely that the Attorney General will have virtually a free hand in the manner in which he uses such a hearing to formulate an opinion. Despite the specific requirement of a finding under the old Section 23, the Attorney General was permitted in Dolenz to make a determination that an alien would not be persecuted merely by weighing the testimony of the claimant himself and of two "expert" witnesses called by the claimant. It seems probable that under the looser wording of the new law few courts would require the Attorney General to do more than similarly hear and evaluate evidence offered by the alien.

By possibly eliminating a full hearing on the issue of physical persecution and by granting the Attorney General a broad discretion to deport in any event, Section $243(\mathrm{~h})$ may exceed the limits of constitutionality. At present, ordinary deportation proceedings against a resident alien must be carried out in accordance with procedural due process ${ }^{16}$ Denial of such safegutards as at

15. Under the provisions of 62 STAT. 1206 (1948), 8 U.S.C. \$ 155(c) (Supp. 1951), involving the discretionary power of the Attorney General to suspend deportation in cases of economic hardship, some courts have held that a hearing in accordance with procedural due process is required. United States $c . r$ rel. Weddeke v. Watkins, 1606 F.2d 369 (2d Cir.), cert. denied, 333 U.S. 876 (1948) ; Kavadias v. Cross, 82 F. Supp. 710 (N.D. Ind. 1948). But $\S 155$ (c) called for a "finding" rather than an "opinion" when these cases were decided. And $c f$. United States $e x$ rel. Zabadlija v. Garfinkel, 77 F. Supp. 751 (W.D. Penn. 1948) (Immigration Board does not have to suspend deportation proccedings and grant a hearing on alien's contentions of economic hardship). In addition, the $W r d-$ deke and Kavadias cases seem to have been based on the fact that the Attorney General's regulations had provided for a quasi-judicial procedure to determine eligibilty for suspension under $\S 155$ (c). 8 CODE FED. REGS. $\S 150.6$ (1949).

Under a related section of the Immigration Laws prior to 1952 , before an alien could be deported as a public charge a "finding" had to be made by the Attorney General. The 1952 law changes this requirement of a finding to an opinion. For a criticism of this action, see Rep. of President's Consm. on Immigration and Naturalization 206 (1952).

16. "It is true that aliens who have once passed through our gates, even illegally, may be expelled only after proceedings conforming to traditional standards of fairness encompassed in due process of law." Shaughnessy v. United States $c x$ rel. Mezei, 21 U.S.L. WeEk 4242, 4243 (U.S. March 16, 1952). See also Wong Yang Sung v. McGrath, 339 U.S. 33 (1949) ; Kaoru Yamataya v. Fisher, 189 U.S. 86 (1902); United States c.t rel. Giacalone v. Miller, 86 F. Supp. 655 (S.D.N.Y. 1949) (stuspension proccedings).

The due process protection which applies to deportation proceedings, however, may be of a more restricted nature than that which applies to ordinary criminal proceedings. Zakonaite $v$. Wolf, 226 U.S. 272 (1912); United States v. Zimmerman, 94 F. Supp. 22 (E.D. Penn. 1950) (strict adherence to judicial procedure not required in a hearing in deportation 
fair hearing and a right to have a decision based solely upun that hearing constitutes an improper deprivation of "life, liberty, or property" within the meaning of the Fifth Amendment. ${ }^{17}$ Under current world conditions, resolution of the question of whether or not an alien will be persecuted upon arrival at his ultimate destination certainly has as serious an effect on his life or liberty as does the initial decision to deport hin. Hence, the Fifth Amendment would seem to require both that such a determination be accompanied by at least equal procedural safeguards and that suspension of deportation he mandatory where a hearing indicates that the alien's claim is valid. ${ }^{18}$

proceedings); Vajtauer v. Commissioner, 273 U.S. 103 (1927) (rcquirements of duse process satisfied if deportation order is based on some evidence). But if. Bridges $v$. Wixon, 326 U.S. 135 (1944) (order of deportation nust be based on subsfastial evidence).

Despite the severity of the penalty, the courts have unanimously hold that deportation matters are entirely civil in nature. Sce Carlson v. Landan, 342 L.S. 454 (1952) ("Deportation is not a criminal proceeding and has never been held to he runishment. No jury sits. No judicial review is granted by the Constitution.").

The Immigration and Nationality Act, $\$ 242$, provides for full hearings on the question of deportability. The law states that administrative regulations promulgated under $\S 2+2$ must include provisions giving the alien the right to counsel of his own choosing; a reasonable opportunity to examine evidence against him, to present evidence on his own behalf, and to cross-examine witnesses presented by the Government. Pub. L. No. 414, \&2d Cong., 2d Sess. $\$ 242$ (June 27, 1952). This hearing, however, is confingd to questions of determination of deportability.

17. "A full and fair hearing on the charges which threaten his deportation ... is indispensable to the lawful deportation of an alien. . . . An alien, as well as a citizen, is protected by the prohibition of deprivation of life, liberty or property without due process and the equal protection of the law." Whitfield v. Hanges, 22 Fed. 745, 743 (Sth Cir. 1915). See also Bridges v. Wixon, 326 U.S. 135. 154 (1944); Hays v. Hatges, 94 F.2d 67, 68 (Sth Cir. 1938) ; Ex Parte Kurth, 2S F. Supp. 258, 260 (S.D. C31. 1939); United States ex rel. v. Van De Miark, 3 F. Supp. 101, 102 (W.D.N.Y. 1933).

The right to a fair hearing includes the right "that the decision shall be gorernel by and based upon the evidence at the hearing, and that only." Whitfield $v$ Hanges. 222 Fed. 745, 749 (8th Cir. 1915). See also Lngar v. Seaman, 4 F.2d 80, 83 (8th Cir. 1924).

Numerous decisions have outlined the prerequisites for a fair haring. Ses, c.y. Gonzales v. Zubrick, 45 F.2d 934 (6th Cir. 1930) (right to examine available witnesces); Ex Parte Keisukisita, 215 Fed. 173 (N.D. Cal. 1914) (opportunity for alisn to controvert adverse evidence); Ex Partc Kurth, 2S F. Surp. 2S\$ (S.D. Cal. 1939) (right to counsel).

The Supreme Court has frequently pointed to the severe conscguences of ordinary deportation. See Nig Fung Ho r. White, 259 U.S. 276 (1922) (deportation "may result ... in loss of both property and life, or of all that makes life worth living"). See also, Fong Haw Tan v. Phelan, 333 L.S. 6 (1948); sec Fong Yue Ting v. United States, 149 U.S. 689, 732-44 (1893) (dissent). And see, Konviz, Aluen A:id Asmitre 1: Anerican Law c. 2 (1946) ; McGovney, Depurtation of Aliens, 18 low L. Rem. 187, 183 (1932).

18. The statement of one district court judge may be interpretcd as extending the full protection of due process to suspension pruceedings when they involve a possible deprivation of life or liberty. "An alien who avails himself of a provision of law concerning a matter so vital that his very life and liherty may depend unon its just applietion is entitled to the thorough and surrounding protection of the Fifth Amendment." United States exr rel. Watts v. Shaughnessy, 107 F. Supp. 613, 615 (S.D.X.Y. 1952). 
Regardless of possible constitutional defects, the discretionary nature of the power granted the Attorney General under the new law seems likely to eliminate effective judicial review. ${ }^{10}$ Some courts dealing with actions of the Attorney General under similar statutory grants of discretionary authority have indicated that no review is available. ${ }^{20}$ Others have held that review will be granted only when there has been a serious abuse of discretion or a failure to exercise discretion at all. ${ }^{21}$

A fair appraisal of the impact of persecution on deported aliens suggests the need for at least the minimum procedural safeguards implicit in the "finding" required by the 1950 Act. Under that Act a hearing on the persecution question was held only after an alien was first found to be deportable. Since most deportation cases do not involve any issue of physical persecution, stuch a procedure appears proper. Once the issue is raised, however, the Government should not be permitted to dismiss reasonable claims summarily. Hence, where the alien introduces valid evidence to support his contentions, an adverse decision by the Attorney General should be permitted only where the Government introduces adequate rebutting evidence. And the entire procedure should be open to judicial review. Such protection for the alien would not

19. See Communication to YALE LAw JourNaL from Senator Fubert H. Humphrey (D. Minn.), dated Jan. 23, 1952, in Yale Law Library. See also President 'Truman's Message to Congress, accompanying his veto of the McCarran Act, N.Y. Times, June 26, 1952, p. 4, col. 7 .

20. See, e.g.; Sleddens v. Shaughnessy, 177 F.2d 363 (2d Cir. 1949) (suspension of deportation is a matter of discretion which the court is without power to review); United States ex rel. Walther v. District Director, 175 F.2d 693 (2d Cir. 1949) (the word "may" when used in a statute relating to suspension of deportation confers discretionary unreviewable power upon the Attorney General); United States e.t rel. Zabadlija v. Garfinkel, 77 F. Supp. 751 (W.D. Penn. 1948) (when a statute has coniferred discretionary power on an executive department, the court cannot interfere with this exercise of discretion).

21. Section 23 of the Internal Security Act of 1950 amended former provisions in regard to the granting of bail to aliens pending determination of deportability by inserting "in the discretion of the Attorney General." 64 STAT. 987 (1950), 8 U.S.C. $\$ 156$ (Supp. 1951). In Carlson v. Landon, 342 U.S. 524, 534 (1952) the Court said, "It [the Attorney General's discretion upon the granting of bail] can only be overridden where it is clearly shown that it 'was without a reasonable foundation.'"

For instances of limited judicial review over the Attorney General's discretionary power to suspend deportation in cases of economic hardship, see Mastrapasqua v. Shaugh nessy, 180 F.2d 999 (2d Cir. 1950); United States ex rel. Kaloudis v. Shaughnessy, 180 F.2d 489, 490 (2d Cir. 1950); U.S. ex rel. Weddeke v. Watkins, 166 F.2d 369 (2d Cir.), cert. denied, 333 U.S. 876 (1948); Kavadias v. Cross, 82 F. Supp. 716 (N.D. Ind. 1948), rev'd on other grounds, 177 F.2d 497 (7th Cir. 1949). See also Note, 60 YALE L.J. 152 (1951).

For instances of limited judicial review over discretionary administrative actions in regard to voluntary departure of deportable aliens under 54 STAT. 671 (1940), 8 U.S.C. $\S 155$ (c) (1946), see United States ex rel. Bartsch v. Watkins, 175 F.2d 245 (2d Cir. 1949); United States ex rel. Von Kleczkowski v. Watkins, 71 F. Supp. 429 (S.D.N.Y. 1947). 
impose too great a duty on the Immigration Service. As suggested by one district court under the 1950 Act, the informational resources of the State and Justice Departments could be properly utilized by the Immigration officers to promote a fair decision. ${ }^{22}$ Once a determination is made that an alien arill be persecuted in a given country, suspension of deportation to that country should be mandatory.23

For the past year, the United States has vigorously fought against a Korean truce which would require that North Korean and Chinese communist prisoners of war be sent back to "slavery [or] almost certain death. ...." Arguing both on the basis of the humanitarian goals of the United Nations Charter and the Geneva Convention of 1949, this Government talies the position that it cannot properly return these individuals involuntarily to physical persecution. ${ }^{25}$ But if, under international agreements dealing with general principles of humanitarianism, the United States feels obliged to refuse to send prisoners of war back to such treatment, certainly the more specific prutection afforded to aliens by the Bill of Rights should compel the Government to refrain from arbitrarily sending relatively harmless civilian alicns to a similar fate. ${ }^{26}$ Frequent disregard by the Attorney General of aliens" claims in past

22. See Park v. Barber, 107 F. Supp. 605, 607, (N.D. Cal. 1952).

Moreover, such an inquiry does not involve an evaluation of comples scientific or economic data like that presented in many administrative determinations. A just and reasonable decision could therefore be quickly reachcd once an adequate investigation has been made.

23. The continued presence of the alien within the country as a result of such mandatiry suspension would not weaken the nation's security. Under present law, for a period of six months subsequent to a final order of deportation "the alien may be detairsd, [or] released on bond in an amount and containing such conditions as the Attomey General may prescribe. ..." Pub. L. No. 414, \$2d Cong., 2d Sess. (June 27, 1952). In addition, if after six months, "deportation has not been practicable, advisable, or possible, or departure of the alien from the United States under the order of deportation has not bren effected," the alien becomes subject to further supervision. Id. at $\$ 242(\mathrm{c})$. The regulations for such supervision may include provision for periodic reports to be made by the alien to an immigration official; submission, if necessary, to mental and/or physical es: aminations; and the giving of such information under oath which the Attorney General "may deem fit and proper." Moreover, the alien must "conform to such reaconable written restrictions on his conduct or activities as are prescribed by the Attorney General in his case." Refusal to comply with any of the above requirements may result in conviction of a felony. Ibid.

24. President Harry S. Truman, quoted in N.Y. Times, Aug. 21, 1952, p. 1, col. 4.

See also Charmatz \& Wit, Repatriation of Prisoners of War and the 19.9 Geneza Convention, 62 YALE L.J. 391, 392 (1953) ("Past treatment given repatriated nationals of communist countries convinced the leaders of the Western powers that Chinese and North Korean prisoners on their return would be exposed to deprivation of human rights.").

25. For a full discussion of the problems involved in forcible repatriation of prisoners of war, see Charmatz \& Wit, stpra note 24 , fassin.

26. The full protection of the Bill of Rights applies to aliens and citizens alike. Bridges v. Wixon, 326 U.S. 135 (1944) ; United States v. Pink, 315 L.S. 203 (1943); Kwodi Jan Fat v. White, 253 U.S. 454 (1920); Wong Wing v. United States, 163 U.S. 223 (1896); Yick Wo v. Hopkins, 118 U.S. 356 (1886). 
persecution cases ${ }^{27}$ indicates the extreme danger inherent in the complete lack of safeguards now available to an individual for whom deportation may mean persecution. Section $243(h)$ of the Immigration and Nationality Act of 1952 should be redrafted so as to affirm "our historic tradition of affording asylum to the persecuted." 28

27. The courts have criticized the Immigration authorities' actions under $\$ 23$ for being contrary to the proven facts and to a fair evaluation of the evidence presented (in the suspension hearings). United States $e . x$ rel. Watts v. Shaughnessy, $107 \mathrm{~F}$. Supp. 613, 617 (S.D.N.Y. 1952). The Immigration Service has also been rebuked for lightly dismissing testimony as to physical persecution. United States $e x r c l$. Chen Ping Zee v. Shaughnessy, 107 F. Supp. 607, 608 (S.D.N.Y. 1952).

28. See United States ex rel. Watts v. Shaughnessy, 107 F. Supp. 613, 615 (S.D.N.Y. 1952) ("[Section 23 of the 1950 Act] is, by strong analogy, consonant with otur historic tradition of affording asylum to the persecuted, a tradition which reaches back beyond the birth of the Fifth Amendment itself.").

Some legislators have suggested that not only should statutory protection equivalent to that of the 1950 law be provided, but that it should be extended beyond mere physical persecution. In S. 2842 (1952) (a bill offered in opposition to the McCarran bill and subsequently rejected) the words "or persecution of any kind because of race, religion, or political opinions" were added to the pertinent provision. Communications to YALE LAW JourNal from Senator Hubert H. Humphrey (D. Minn.), dated Jan. 23, 1953, and Senator Herbert H. Lehman (D. N.Y.), dated Mar. 17, 1953, in Yale Law Library.

The 83d Congress will consider at least two bills directed towards revision of the McCarren Act. Representative Barrett of Pennsylvania has announced his intention to submit a bill which would entirely repeal the legislation. Representative Javits of New York has presented a bill calling for a rewriting of the law. N.Y. Herald Tribunc, Jan. 4, 1953, p. 5, col. 3. In addition, President Eisenhower has indicated his desire to see a change in the law as it now stands. See N.Y. Times, Mar. 17, 1953, p. 1, col. 5. 